University of Nebraska - Lincoln

DigitalCommons@University of Nebraska - Lincoln

Faculty Publications: Department of Teaching, Department of Teaching, Learning and Teacher Learning and Teacher Education

2017

Interpreting Early Career Trajectories

Joan Barnatt

Dianna Gahlsdorf Terrell

Lisa Andries D’Souza

Cindy Jong

Marilyn Cochran-Smith

See next page for additional authors

Follow this and additional works at: https://digitalcommons.unl.edu/teachlearnfacpub

Part of the Curriculum and Instruction Commons, and the Teacher Education and Professional

Development Commons

This Article is brought to you for free and open access by the Department of Teaching, Learning and Teacher Education at DigitalCommons@University of Nebraska - Lincoln. It has been accepted for inclusion in Faculty Publications: Department of Teaching, Learning and Teacher Education by an authorized administrator of DigitalCommons@University of Nebraska - Lincoln. 


\section{Authors}

Joan Barnatt, Dianna Gahlsdorf Terrell, Lisa Andries D’Souza, Cindy Jong, Marilyn Cochran-Smith, Kara Mitchell Viesca, Ann Marie Gleeson, Patrick J. McQuillan, and Karen Shakman 


\title{
Interpreting Early Career Trajectories
}

\author{
Joan Barnatt,, Dianna Gahlsdorf Terrell, ${ }^{2}$ \\ Lisa Andries D'Souza, ${ }^{3}$ Cindy Jong, ${ }^{4}$ \\ Marilyn Cochran-Smith, ${ }^{5}$ Kara Mitchell Viesca, ${ }^{6}$ \\ Ann Marie Gleeson, ${ }^{7}$ Patrick McQuillan, 5 \\ and Karen Shakman ${ }^{8}$
}

\author{
1 Elon University, Elon, NC \\ 2 Saint Anselm College, Manchester, $\mathrm{NH}$ \\ 3 Assumption College, Worcester, MA \\ 4 University of Kentucky, Lexington, KY \\ 5 Boston College, Chestnut Hill, MA \\ 6 University of Colorado, Denver, $\mathrm{CO}$ \\ 7 Primary Source, Watertown, MA
}

8 Education Development Center, Inc., Waltham, MA

Corresponding author - Joan Barnatt, School of Education, Elon University,

CB 2105, Elon, NC 27244, USA. Email: jbarnatt@elon.edu

\begin{abstract}
Career decisions of four teachers are explored through the concept of figured worlds in this qualitative, longitudinal case study. Participants were purposefully chosen for similarity at entry, with a range of career trajectories over time. Teacher career paths included remaining in one school, repeated changes in schools, attrition after relocation, and nonrenewal of contract. Data included interviews, observations, participants' assessments, and pupils' work. Cross-case analysis suggests that no
\end{abstract}

Published in Educational Policy 31:7 (2017), pp 992-1032.

DOI: 10.1177/0895904815625286

Copyright (C) 2016 Joan Barnatt, Dianna Gahlsdorf Terrell, Lisa Andries D’Souza, Cindy Jong, Marilyn Cochran-Smith, Kara Mitchell Viesca, Ann Marie Gleeson, Patrick McQuillan, and Karen Shakman. Published by SAGE Publications. Used by permission. Published January 12, 2016. 
single teacher attribute or workplace condition determined teachers' career decisions; rather, teachers' ability to refigure their identity within the figured world of teaching shaped career trajectory. Key factors such as ability to address disequilibrium, teacher identity, agency, and collaborative capacity are examined. Implications call for pre-service preparation and professional development to navigate cultures of schools, amended administrative involvement in teacher retention, and policy reform acknowledging the complexity of teachers' figured worlds.

Keywords: teacher retention and turnover, teacher preparation, educational policy, qualitative research

Currently, there is broad consensus that teachers play a crucial role in students' learning and academic success (Cochran-Smith \& Villegas, 2015; Darling-Hammond, 2013; Tamir, 2014). Many have argued that the quality of the education system, and particularly the quality of teachers, determines a nation's ability to compete in the global knowledge economy (e.g., Furlong, Cochran-Smith \& Brennan, 2013; McKinsey \& Company, 2009; Organisation for Economic Co-Operation and Development, 2005). Accordingly, in the United States and elsewhere, the recruitment, preparation, and retention of teachers has become a central concern of top-level leaders in the business, philanthropic, and policy-making worlds as well as in the professional arena (DarlingHammond, 2010; Oakes, Lipton, Rogers, \& Renee, 2006). As a consequence of this, policy leaders and reform advocates have focused increased attention on developing teacher accountability systems, which among other things seek to define teacher quality in terms of how much value a teacher adds to student achievement (Goldhaber \& Hansen, 2013; Measures of Effective Teaching [MET] Policy and Practice Brief, 2013). Similarly, attempts at connecting teacher preparation programs directly to K-12 student outcomes are growing in popularity (Cochran-Smith et al., 2012; Diez, 2010; Henry et al., 2013; National Council on Teacher Quality, 2013).

While teacher quality has been identified as an essential factor in school and economic success, a severe problem in teacher retention has emerged, with as many as $20 \%$ of new teachers leaving the profession within the first 3 years (Henke, Chen, \& Geis, 2000), and almost 50\% leaving within the first 5 years (Ingersoll, 2003). In addition, with growing dissatisfaction for a variety of reasons among those teachers who remain in the profession (Hargreaves \& Fullan, 2012; Jacob, Vidyarthi, \& Carroll, 2012), increasing numbers of veteran, 
high-quality teachers described as "irreplaceables" in terms of what they bring to the classroom are now leaving teaching at nearly similar rates as novice teachers (DeAngelis, Wall, \& Che, 2013; Jacob et al., 2012). With major reform initiatives deeply impacting teachers' lives (e.g., new teacher evaluation systems, Common Core State Standards, and aligned assessments), a more comprehensive and nuanced understanding of teachers' lives, the worlds in which they work, and the career decisions they make is necessary to create and sustain policies and practices that retain teachers who exhibit characteristics of quality practice in the profession.

Our study of teachers' lives, worlds, and career decisions focuses on four novice teachers, all "highly qualified," according to the federal mandate. The case study participants were selected for this study because they were all young, White, middle class, and female, with strong academic backgrounds and genuine commitments to teaching. All attended the same master's-level teacher preparation program at a highly selective university. Each teacher began her professional career in a school or district similar to where she student taught, was given a content-appropriate teaching assignment, and was assigned a mentor. We chose these four teachers because despite these striking similarities, the experiences and outcomes for these four teachers were remarkably different, which led to our research question:

Research Question: What explains differences in the career trajectories for beginning teachers whose backgrounds, training, and entrance into the profession were similar?

Based on a consensual qualitative analysis (Hill et al., 2005; Hill, Thompson, \& Williams, 1997) and within- and across-case analysis (Stake, 2013), we suggest that differences in these four teaching careers cannot be explained simply by the presence or absence of single factors or policies, such as the recruitment of teachers from highly regarded institutions, or the alignment of teachers' initial teaching assignments with their preparation. Rather, we propose the variation in career trajectories is better explained by how novice teachers "figure" their teaching world, how that teaching world interacts with and responds to the teacher, and in turn how teachers "figure" themselves into the world of teaching (Holland, Lachtcotte, Skinner, \& Cain, 1998). 


\section{Literature Review: Studies of Teacher Attrition or Retention}

Studies of attrition and retention generally focus on one of three sets of variables as catalysts influencing teachers' career decisions in this regard (Boyd et al., 2011; DeAngelis et al., 2013; Hong, 2010). These include (a) characteristics of teachers including demographic, professional, and affective traits of teachers (Borman \& Dowling, 2008); (b) characteristics of schools including administrative and organizational support (Kraft \& Papay, 2014), and induction and mentoring programs (Ingersoll \& Strong, 2011); or (c) characteristics of students defined by demographic characteristics and traditional measures of academic achievement (Boyd, Lankford, Loeb, \& Wyckoff, 2005; Hanushek, Kain, \& Rivkin, 2004). Studies about teachers' characteristics suggest specific attributes of teachers, and their practice may contribute to or curb attrition from the field. The vast array of characteristics that have been studied-Borman and Dowling (2008) note 63 characteristics in their meta-analysis-provide a fragmented and convoluted vision of attrition issues rather than clear and informative indicators for policy makers and administrators to address, implying that an alternative approach is also required for better understanding of this issue.

To date, a relatively small but growing number of research studies on teachers' characteristics and their impact on attrition/retention explicitly link the observed professional practices of novice teachers with their subsequent career decisions. For example, four syntheses of research in this area (Borman \& Dowling, 2008; Guarino, Santibanez, \& Daley, 2006; Johnson, Berg, \& Donaldson, 2005; Strong, 2005) concluded that retention studies generally did not make connections between attrition/retention and teachers' professional practice, whether defined in terms of students' learning or other specific attributes of professional practice (e.g., expectation, sense of efficacy, networking, and self-advocacy skills). Perhaps this shortcoming can be explained by the fact that many attrition/retention studies are quantitative in nature, and rely on large data sets including the Schools and Staffing Survey (SASS) and the Teacher Follow-Up Survey (TFS; Boyd et al., 2011). This methodological restriction obscures observable characteristics of teaching practice including the exchange of ideas between individuals and the contexts in which they learn to teach. As such, there is no way to explore the relationship between unquantifiable 
aspects of teacher characteristics and teachers' retention in or attrition from the field with large data sets and quantitative methodologies alone. Fewer studies make use of firsthand accounts and reflections in the form of interview data, and our literature review uncovered a dearth in attrition/retention studies derived from case studies of novice teachers' practice that include both observation and interview data.

Since the time of these syntheses, however, more recent studies have explored the connection between retention/attrition and teacher characteristics linked to quality professional practice. Among these newer studies, there is an emerging consensus that less effective teachers (defined in terms of value added to students' test scores) are more likely to leave teaching than more effective teachers (Boyd et al., 2011; DeAngelis et al., 2013; Goldhaber, Gross, \& Player, 2011; Hanushek et al., 2004; Krieg, 2006). Yet again, in large part, these studies draw from data sets and/or teacher self-report rather than direct observation of teaching practice. Thus, there is an added obstacle in theorizing how these teachers' internal thoughts and exchanges between teachers and the school world inform their professional actions.

Several attrition/retention studies that focus on teacher characteristics have outlined the critical nature of teachers' affective attributes in subsequent career decisions, including teachers' sense of efficacy, emotional well-being, networking capacity, and aptitude to persevere in the face of adversity. A few studies have described the importance of teachers' expectations about the profession, including the influence they expect to exert in schools. For example, Hammerness (2008) concluded that over 8 years, teachers moved to new schools primarily for pedagogical reasons, particularly whether or not their "visions" about ideal classroom practice matched the reality of the school. Olsen (2008) suggested that the early development and career decisions of teachers from the same urban preparation program centered on their expectations and reasons for entering teaching, which shaped their evolving identities as teachers. Hong (2010) cautioned that over-idealized expectations of teaching appeared to lead to burnout and, as such, there is a critical but "fine line between healthy optimism and unrealistic idealism” (p. 1540).

Relatedly, several studies by Susan Moore Johnson and colleagues (Donaldson \& Johnson, 2010; Johnson \& Birkeland, 2003; Johnson \& The Project on the Next Generation of Teachers, 2004; Liu \& Johnson, 
2006) suggest that "efficacy," or whether teachers achieve a sense of success in their work with students, is among the most important determinants of beginning teachers' decisions about staying, leaving, or moving schools. Johnson and colleagues maintain that negative working conditions (e.g., lack of support from principals or colleagues) contribute to teachers' low sense of efficacy, which in turn leads to increased voluntary turnover. Boyd et al. (2011) continue this line of argumentation finding that novice teachers' evaluation of their own preparedness for teaching is correlated with career decisions. In this study, novice teachers who express less satisfaction with their preparation path reported lower self-efficacy, and were at greater risk for planning to leave and subsequently leaving the teaching field (Boyd et al., 2011).

Meanwhile, several studies (Freedman \& Appleman, 2009; Hong, 2010, 2012) highlight how emotional well-being can impact teachers' attrition and retention in the field. Freedman and Appleman (2009), for example, found that candidates from one preparation program stayed in urban teaching because of a sense of mission, persistence, and a disposition for hard work. Hong (2010, 2012) measured the emotional well-being of novice teachers according to six criteria (value, self-efficacy, commitment, emotions, knowledge and beliefs, and micropolitics) and found that emotional burnout was a "critical issue" (Hong, 2010, p. 1539) for the professional lives of novice teachers and that "unfulfilled commitment and lack of efficacy" were contributing factors of emotional burnout (Hong, 2010, p. 1539). Very recent studies have found that affective attributes such as "grit" and perseverance (Robertson-Kraft \& Duckworth, 2014) as well as novice teachers' capacity to network with and engage in healthy professional learning communities (Tamir, 2013) serve to mitigate some of the professional and emotional challenges associated with being a novice classroom teacher. These affective characteristics of teachers and the professional learning communities in schools serve to enhance and fortify fledgling teachers' professional identities and hence their longevity in the classroom.

These studies in combination suggest that the very characteristics that lead to increased retention-realistic expectations, a capacity to network, and to exhibit agency-are also in many cases identified as hallmarks of high-quality professional practice (Hammerness 
et al., 2005; Interstate New Teacher Assessment and Support Consortium [INTASC], Special Education Subcommittee, 2001) and may fortify tendencies that stayers exhibit like perseverance or "grit" and a sense of efficacy. Yet, an acknowledged shortcoming of attrition and retention studies is that they primarily draw from large, quantitative data sets and self-report survey instruments to identify teacher characteristics associated with retention and attrition (Boyd et al., 2011). Although it is not the intention of these studies to do so, they do little to describe or conceptualize the internal reflection, dialogue, and reformation of identity that foster the development of desired characteristics in novice teachers. Indeed, Tamir (2013) argues that education researchers need to better understand how teachers "negotiate their role and place in schools" (p. 29). This suggests the need to explore how novice teachers reflect upon the affective qualities they bring to the teaching profession, how those qualities play out in observed teaching and professional practice, the interaction between teacher and school context, and how novice teachers build, tailor, and refine their professional identities and actions over time.

\section{Theoretical Frame}

Sociocultural theory as it relates to learning to teach identifies this process as occurring through interactions between and among a teacher and the multiple stakeholders in the school community including students, administrators, colleagues, mentors, supervisors, families, as well as professional learning communities that exist beyond the school walls. Drawing from the concept of communities of practice (Cuddapah \& Clayton, 2011; Lave, 1991, 1993; Lave \& Wenger, 1991; Wenger, 1998), learning to teach in a school involves not only negotiating classroom practice, certainly, but also understanding the demands, policies, expectations, and interpretations of a particular context and overlapping-and sometimes competing-groups. Furthermore, a sociocultural perspective of learning to teach assumes a continuous change within these spheres that include shifting individual relationships, organizational demands, and policy reform, for example. Individually and collectively, teachers and members of a particular community work to make sense of the change and their place within the structure. 
From within this broad sociocultural perspective, we use the work of Holland et al. (1998), particularly their conceptualization of identity and figured worlds, to understand the various trajectories that novice teachers take in their professional lives. According to Holland and colleagues, figured worlds are historically grounded, social, and cultural constructions, which encompass structures of power, relationships, and actions in particular cultural realms. These social spheres evolve in an ongoing process of change and interpretation occurring on an individual level and within a cultural context. In our work, we use this theory to unpack the figured worlds of four individuals as they prepare for and enter the profession of teaching. Their responses, decisions, and actions in negotiating these figured worlds provide a means of understanding the expectations, contexts, agency, power, and ultimately, career decisions that each graduate makes during their early years of teaching.

Drawing on the work of Bakhtin (1981), Holland et al. (1998) describe figured worlds as dialogic, where sense-making is a response to internal dialogues based on social negotiations prompted by selfconstructed contextual labels (e.g., student, effective teacher, highly qualified) and responses within the frame of meaning (i.e., the figured world of classrooms, schools, education as a profession) that provides a context for understanding, responding, and acting. The actions of the individual influence the world at large, even as the actions and understandings of the participant are shaped by the understandings of culture and expectations. Holland et al.'s (1998) work also encompasses the ideas of Vygotsky $(1978,2012)$ and his emphases on cultural symbols and historical development. Thus, Holland et al. (1998) note, "We aim to build upon and move beyond two central approaches-the culturalist and the constructivist - to understand people's actions and possibilities" (p. 8).

Holland et al.'s (1998) sociocultural theory of figured worlds has proven to be a useful tool for research in education in a variety of applications. For example, Leander (2002) and Urrieta (2007) explored educational contexts and identity of students, while Luttrell and Parker (2001), Bartlett (2007), and Hatt (2007) studied sociocultural concepts such as literacy and "smartness." Blackburn (2002) addressed LGBTQ issues in an imagined world; similarly, Jurow (2005) used a "possible" figured world to study student mathematical learning in 
project-based curriculum. Furthermore, a number of researchers have addressed questions of how identities emerge from a variety of educational contexts (Boaler \& Greeno, 2000; Dagenais, Day, \& Toohey, 2006; Luttrell \& Parker, 2001; Ma \& Singer-Gabella, 2011; Michael, Andrade, \& Bartlett, 2007; Rubin, 2007; Sloan, 2006).

The study presented here draws significant parallels to applications of figured worlds in the work of Sloan (2006), C. Robinson (2007), and Ma and Singer-Gabella (2011), each of whom addressed the manner in which teachers and teacher candidates interacted with and were able to "figure themselves" into teaching contexts.

Throughout the theoretical literature on figured worlds, there is one line so clear in meaning and perhaps so obvious in its implications that it is quoted in many studies: "People tell others who they are, but even more important, they tell themselves and then they try to act as though they are who they say they are" (Holland et al., 1998, p. 3). Drawing on this perspective, we sought to understand how each of our participants "told others who they thought they were." Then, we sought to understand how they fashioned and refashioned their identity in response to the contexts they encountered and how all of this shaped their career trajectories.

Fecho, Graham, and Hudson-Ross (2005) note that people appear to occupy many figured worlds simultaneously "with each of those figured worlds flavoring experience in any other" (p. 178). In situating themselves in these figured worlds, individuals sometimes experience "dissonance" (C. Robinson, 2007, p. 205). Fecho et al. (2005) refer to the response to this dissonance as "wobble" or the "space of uncertainty that lies between and among figured worlds," which creates an "unsettling state of vertigo" (p. 175). In other words, wobble occurs when the image of self an individual holds and presents to others conflicts with one of the many figured worlds she or he occupies.

This study draws heavily from the concept of "wobble" from Fecho et al. (2005), yet the term conveys that those experiencing wobble inevitably regain their balance. In contrast, on many occasions our participants did indeed fall, and did not regain their balance. For that reason, this study refers to these as moments of "disequilibrium." Working from the concept of disequilibrium, we identified critical moments in the early teaching experiences of the teachers we followed. In each of these cases of disequilibrium, it becomes clear that 
the disequilibrium is brought about through the exchange between the actor and the organizational structures and contexts rather than a disequilibrium that emerges within the actor herself. This underscores the bedrock principles of sociocultural theory, which treats social contexts as an "integral component, not just a container, for intellectual activity" (Spillane, Halverson, \& Diamond, 2001, p. 23).

This study identifies and analyzes such moments of disequilibrium, and offers theories as to why individuals experience and react to moments of disequilibrium with such a broad array of responses. As noted, there is very little research that links direct observations of teaching practice with early career decisions. However, from the literature, we identified two closely related constellations of factors that seem important: those involving teachers' expectations about teaching practice and their subsequent sense of efficacy and emotional well-being derived from realizing or failing to realize expectations, and those that allow novice teachers to exhibit agency and a capacity to collaborate, mitigate, negotiate, and persevere in the face of adversity. These factors informed our analysis seeking to understand the differences in career trajectories of four beginning teachers and how they figure their teaching world, how the teaching world responds and is reshaped by them, as well as how they figure themselves into the world of teaching. Unlike other conceptions of retention and persistence that analyze an individual's "fit" within an organization (Youngs, Pogodzinski, Grogan, \& Perrone, 2015), this analysis explicitly recognizes the iterative nature of career decisions, and analysis of that decision making requires honoring all players, artifacts, and contexts involved in these exchanges. While some studies of teachers or teacher candidates that operate from this framework uncover the process of an individual figuring themselves (Ma \& Singer- Gabella, 2011; Urrieta, 2007), other studies clarify how individuals figure the world around them (Fecho et al., 2005; Michael et al., 2007; Rainio, 2008), while still others address both perspectives in some fashion (C. Robinson, 2007; Rush \& Fecho, 2008; Sloan, 2006). None, however, consider teacher retention and attrition from the frame of figured worlds, as we do here. For these teachers, as newcomers to the profession and the particular figured world of a school, the ability to influence or reshape the institution is, not surprisingly, overshadowed by the individual's efforts to understand and respond to the world of the workplace. Nonetheless, the context in which each teacher finds herself provides 
a cultural frame and social responses that shape and remold both entities so that neither remains in stasis. This study suggests that it is the dynamic interplay of these figured identities, and the disequilibrium that emerges when the worlds are misaligned, that appears to dictate a teacher's decision to stay or leave a teaching position. In the "Implications" section, this theory is expounded on, considering conditions under which these moments of disequilibrium might be mitigated.

\section{Method}

This research is based on data from four case studies derived from a larger longitudinal study that followed teacher candidates from entry into a teacher education program through 3 years of teaching. The teacher candidates were enrolled in the same highly selective 1-year, master's-level teacher education program at a Jesuit university with approximately 15,000 undergraduates and graduate students. The 22 participants were volunteers from a pool of 150 master's-level candidates. The participants' demographic characteristics were similar to those of the larger program population in terms of school level, certification area, race/ethnicity, gender, age, and educational pattern. As a Jesuit university, the teacher education program is driven by a mission to enhance the human condition, and to make the world more just. In addition, the teacher education program has a central focus on improving urban education.

The four participants selected for analysis in this study represent a purposive sample (Teddlie \& Yu, 2007) and were chosen for several reasons. We chose two secondary-level participants and two elementary-level participants to examine teacher experiences across various grade levels. All four participants had similar background and demographic characteristics in terms of age, academic preparation, and gender; specifically, they were White, in their early twenties, and had strong academic backgrounds. The two teachers in secondary education had appropriate undergraduate majors. All four successfully passed the state licensure exams and earned state certification. By the standards outlined by No Child Left Behind Act of 2001 (No Child Left Behind [NCLB], 2002), all were highly qualified. Finally, each participant in this study had a complete set of data from entry into the study to either exit from teaching or the end of the study. 
Table 1. Data Sources Collected and Analyzed for Each Participant (4) in This Study.

\begin{tabular}{llc} 
Data sources & Description & $\begin{array}{c}\text { Sources gathered } \\
\text { for each participant }\end{array}$ \\
\hline Participant interviews & 6o-120 min interviews & 12 \\
Participant observations & $60-120$ min observations & 7 \\
Field notes & Researcher impressions & varies \\
Teacher education & Sampling of assignments & $1-4$ \\
coursework & including inquiry project & \\
Auxiliary interviews & Interviews with cooperating & 4 \\
& teacher and university supervisor & \\
& (pre-service year) self-selected & \\
& mentor and an administrator & \\
Samples of pupil work & Assessment tasks and samples & 5 \\
& of pupil work from pre-service & \\
& teaching through first 2 years & \\
\hline
\end{tabular}

\section{Data Sources}

Data for this longitudinal study were collected from 2005 to 2010. Data sources for each case study, which are listed in Table 1, included extensive in-depth interviews with candidates/beginning teachers; detailed classroom observations; interviews with university instructors, supervisors, mentors, and school administrators; candidates' coursework and program materials; and samples of candidates'/beginning teachers' assignments or assessments used in class along with samples of students' work.

\section{Data Analysis}

Data analysis was conducted continuously over a 5-year period as data continued to be collected. As a research team, our data analysis was informed by what Hill et al. (1997) call a "consensual" approach to qualitative data analysis. This approach uses inductive analysis to build explanations from the bottom up, rather than testing hypotheses from the top down. Moreover, with consensual qualitative research, all data are collected using standardized protocols to provide consistency 
across data collection methods as the team of researchers works to arrive at "consensus judgments" (p. 521). Although time consuming, this labor-intensive approach was used for analysis to maintain the integrity of themes that emerged inductively from multiple readings of the data by multiple researchers.

The research team utilized additional measures to ensure reliability. After developing the code list with definitions and examples, each team member coded the same set of excerpts from Interviews 1 to 5, first independently and then with a partner. Then the group collectively examined one coded interview. This recursive process clarified code meaning, leading to a shared understanding of the entire code list. Such a rigorous and iterative process ensured that researchers could code independently with a reasonable degree of reliability.

Following the initial analysis processes across the data set, the research team moved to case analysis and development. According to George and Bennett (2005), the strongest means of drawing inferences from cases is a combination of within-case and cross-case comparisons of a small number of cases. Our analysis involved this two-level approach and is described in detail in the following sections, while this article focuses on the cross-case analysis and findings.

Within-case analysis. The first step in cross-case analysis is to understand the individual case in depth through within-case analysis. Here, the point is to reduce data to get at the essence of the individual case within its context and in terms of its specific conditions (Stake, 2013). Themes or patterns used across cases to help interpret a larger data set must have explanatory power in one case before they are applied more broadly (Ayres, Kavanaugh, \& Knafl, 2003). Informed by Hill and colleagues' (Hill et al., 2005; Hill et al., 1997) “consensual” approach to qualitative analysis, the research team completed within-case analyses in the form of detailed case narratives, drawing on key excerpts from interview and observational data. The structure for each withincase analysis included these categories: (a) entering characteristics; (b) teacher candidates' program experiences; (c) teachers' experience of the first year of teaching, specifically content and pedagogy, learning and assessment, and efforts to teach for social justice; (d) experiences during the second, third, and fourth years of teaching, as above; and (e) career decisions during or at the end of each year of the study. 
The "conceptual infrastructure" (Stake, 2013) or working theory of each case is derived from the interplay of patterns and themes that emerged from the case in its particular context and conditions.

Cross-case analysis. There is a tension in cross-case analysis between maintaining the integrity and particularity of the individual case, on one hand, and identifying themes and patterns that help explain a group of cases, on the other (Ayres et al., 2003). It was our intention to bring into simultaneous view both the local detail of the individual case and more general linkages that help explain teaching practice coupled with career decisions. Collaboratively, the research group identified key elements of the cases, how these played out in individual cases, and how they compared across cases. This process of identifying general analytic categories along with thematic variation allowed the team to develop assertions about teaching practices and career decisions that explained individual cases and extended across the cases. This was a matter of continuous tacking back and forth between what seemed to be larger explanations and how these did/did not mesh with the particular contexts and conditions of individual cases, an iterative process that was repeated multiple times. An abbreviated profile of each of the four participants is provided in Table 2.

\section{Findings}

In the following sections, we begin with a snapshot of each of four participants and then offer cross-case analysis regarding the figured worlds of teaching for the four teachers. We close by reflecting on the complex and layered figured worlds of teaching, and offer implications drawn from this work.

\section{The Tales of Four Teachers}

As previously noted, these four teachers were similar in many respects: White women from middle-class backgrounds, adept students from prestigious undergraduate programs, with teacher preparation from the same very selective institution, and a strong commitment to education as a career. Participants also had differing experiences in 
Table 2. Case Study Participants.

\begin{tabular}{|c|c|c|c|c|}
\hline \multicolumn{2}{|c|}{ Participant Teaching context } & \multirow{2}{*}{$\begin{array}{l}\text { Identity } \\
\text { Came to teaching commit- } \\
\text { ted to improving the life } \\
\text { opportunities of her stu- } \\
\text { dents. Yet she was flexible } \\
\text { in how she approached her } \\
\text { challenges. }\end{array}$} & \multirow[b]{2}{*}{$\begin{array}{l}\text { Disequilibrium } \\
\text { The administration's ex- } \\
\text { pectations for students did } \\
\text { not meet her own. She re- } \\
\text { mained committed to her } \\
\text { goals and reached out to } \\
\text { likeminded colleagues both } \\
\text { inside and outside her } \\
\text { school. }\end{array}$} & \multirow{2}{*}{$\begin{array}{l}\text { Career decision } \\
\text { Elizabeth remained in the } \\
\text { same school in the same } \\
\text { teaching position for } 8 \\
\text { years. }\end{array}$} \\
\hline Elizabeth & $\begin{array}{l}\text { Year 1: present, urban } \\
\text { high school, English } \\
\text { content }\end{array}$ & & & \\
\hline Lola & $\begin{array}{l}\text { Year 1: urban, charter, } \\
\text { secondary, science Year } \\
\text { 2: suburban, predomi- } \\
\text { nately African Ameri- } \\
\text { can, private, secondary, } \\
\text { science Years 3-4: ur- } \\
\text { ban, charter, secondary, } \\
\text { science and math }\end{array}$ & $\begin{array}{l}\text { Commitment to social jus- } \\
\text { tice, high expectations } \\
\text { for school colleagues and } \\
\text { evolving racial identity } \\
\text { are key features of Lola's } \\
\text { identity. }\end{array}$ & $\begin{array}{l}\text { She felt unable to reach } \\
\text { her potential as a high- } \\
\text { quality White teacher } \\
\text { within the contexts, } \\
\text { schools, and communities } \\
\text { to which she was drawn. }\end{array}$ & $\begin{array}{l}\text { Lola decided to leave for } \\
\text { another school within } \\
\text { the year at the first two } \\
\text { schools. At the third school } \\
\text { she stayed believing she } \\
\text { could be successful. }\end{array}$ \\
\hline Riley & $\begin{array}{l}\text { Years 1-3: suburban el- } \\
\text { ementary school, fourth } \\
\text { grade Year } 4 \text { : subur- } \\
\text { ban charter elementary } \\
\text { school, fourth grade }\end{array}$ & $\begin{array}{l}\text { High expectations for self } \\
\text { as teacher and students as } \\
\text { learners, worked collab- } \\
\text { oratively, participated in } \\
\text { multiple professional de- } \\
\text { velopment experiences. }\end{array}$ & $\begin{array}{l}\text { Year 4: principal at new } \\
\text { school used top-down ap- } \\
\text { proach, principal made } \\
\text { racist comment about stu- } \\
\text { dent's family, Riley dis- } \\
\text { agreed with mandated in- } \\
\text { struction approach, no } \\
\text { agency in new school. }\end{array}$ & $\begin{array}{l}\text { Riley resigned in spring of } \\
\text { fourth year because she re- } \\
\text { fused to refigure her iden- } \\
\text { tity to fit the new world } \\
\text { of teaching, which en- } \\
\text { forced opposing views to } \\
\text { learning. }\end{array}$ \\
\hline Elsie & $\begin{array}{l}\text { Year 1: private Catholic, } \\
\text { suburban high school } \\
\text { teaching English lan- } \\
\text { guage arts }\end{array}$ & $\begin{array}{l}\text { Vague expectations for self } \\
\text { as teacher and diminish- } \\
\text { ing student expectations, } \\
\text { worked in isolation, did } \\
\text { not seek support or estab- } \\
\text { lish professional network. }\end{array}$ & $\begin{array}{l}\text { Year 1: developing per- } \\
\text { sonal or professional con- } \\
\text { nections with colleagues } \\
\text { or administration, in un- } \\
\text { derstanding and work- } \\
\text { ing within school envi- } \\
\text { ronment, in establishing } \\
\text { appropriate standards and } \\
\text { expectations for students, } \\
\text { identify as teacher. }\end{array}$ & $\begin{array}{l}\text { Elsie was notified in the } \\
\text { spring of her first year of } \\
\text { teaching that she would } \\
\text { not be rehired, no explana- } \\
\text { tion offered or sought. She } \\
\text { did not seek another posi- } \\
\text { tion in the field, effectively } \\
\text { ending her career after } 9 \\
\text { months. }\end{array}$ \\
\hline
\end{tabular}

\footnotetext{
identify formation and dissonance as they began their teaching lives, which led to differing career trajectories. Here, we drew from Fecho et al.'s (2005) concept of "wobble," to identify key moments and turning points in each graduate's early experiences in the field. For reasons described above, we refer to this phenomenon as "disequilibrium."

Similar to the importance of understanding how these four women formed their teaching identities, understanding when and how they experienced the disequilibrium brought on by exchanges with the
} 
teaching world they inhabited informed our interpretation of their "subsequent behavior" (Holland et al., 1998, p. 4.), including their response to the uncertainty, specifically, and their career decisions more generally. The descriptions below are intentionally limited to key attributes of participants and establishing critical points of disequilibrium, which is then followed by cross-case analysis and theorizing about career decisions. In the subsequent "Cross-Case Analysis: Thematic consistencies and variations" section below, theorized explanations of the cases commonalities and differences are explored.

Elizabeth: Maintaining her center of gravity. Elizabeth Sigel had not given much thought to becoming a teacher until she began tutoring urban youth during her undergraduate education. Her commitment to social justice emerged as a central motivator when she chose to pursue a master's degree in education with an urban focus because she wanted to make students' "lives better-or, [enable them to] make their life the way they want it or envision it . . . by giving them the tools to be able to do with it what they want to do." Elizabeth's lofty-but-tough resolve to improve the life chances of her students was tempered by self-initiated reality checks. Elizabeth understood the larger systematic and structural barriers that prevented most of her students from moving beyond the life they knew, in part because this school was geographically located close to the area she grew up, but also from general knowledge of urban education in the preparation program, and over time because she fulfilled an internship and student teaching here. She sought to establish trust with her students, build relationships with her colleagues, and provide opportunities for students to see the value of an education. To achieve this, Elizabeth was committed to "keeping expectations high and pushing [students] . . . so they're learning to be critical . . . looking at things analytically, ... [T] [hat is really empowering." Elizabeth aimed to push her students to expect more from themselves and recognize the results of sustained hard work. Her identity as a teacher was informed by experiences in the classroom, ongoing professional development, and graduate study opportunities. Above all, her commitment to social justice was enacted as she established challenging, but achievable, expectations for student learning. 
Elizabeth's disequilibrium. Like many urban teachers, Elizabeth's school context provided limited opportunities for collaboration and teambuilding and little recognition for hard work (Jacob et al., 2012). Yet, rather than walking blindly but eagerly into the situation, as many urban educators (Michie, 2012), Elizabeth anticipated how she would work to overcome the difficulties she would face before accepting the position. She had already completed fieldwork and student teaching in the school, and thus, she had already "figured" these school characteristics into her vision of teaching. As such, Elizabeth developed a deep and accurate sense of the culture of the urban school. She understood the necessity of challenging her students with high expectations.

Despite her success, Elizabeth remained frustrated by challenges she faced. At times, she became overwhelmed with multiple class preparations, classroom management issues, and chronic truancy. She bemoaned,

I feel like I'm a blind person sometimes. I'm wandering through dark places and no one comes in to observe me ... I'm frustrated because no one's giving me feedback. [The assistant principal is] under a lot of stress, I know that, but [it] is his job to give me feedback.

She also felt disequilibrium when she saw evidence of diminished expectations for students. In one telling instance at the conclusion of her first year, the administration lowered the school's graduation requirements to accommodate underperforming seniors. Elizabeth fumed,

It goes against what most of us are trying to do which is to set high standards, to hold students accountable, to ensure there's rigor that's met through the whole year, to not let students slip at the end. So in terms of social justice I think that is an absolute disservice to students.

Thus, although Elizabeth had been in some ways prepared for the disequilibrium she experienced when her expectations clashed with the actions of her administration, it aligned with what she identified as problems with public schooling and it reaffirmed her drive to teach the traditionally underserved. This disequilibrium forced Elizabeth to 
continuously rethink her role as a teacher. Rather than lowering her own standards, Elizabeth created a way to get the principal to notice students' high-quality work. For example, she hosted a "publishing party" that showcased her students' literary portfolios. She invited the principal, the deans, janitors, and resource officers to attend. She showcased students' work and, implicitly, the quality of her teaching. Elizabeth was able to overcome her discord with her administrators, while displaying innovation and perseverance, continuing to teach in the school to the present time.

Lola: Dampening the oscillation. Like Elizabeth, Lola Werner's is a case of a new teacher remaining in the profession through her first four years but differs in the sense that Lola did not remain in one school. In these first years of teaching, Lola moved to and through three different schools, making her path erratic and circuitous at times.

Lola spoke with conviction and clarity about what she believed were the markers of a quality teacher or who she "was telling herself she thought she was" (Holland et al., 1998, p. 3). A prominent feature of Lola's figured self was her evolving racial identity and the role that race played in her career choices. Despite being a White woman who hailed from a pervasively White culture in the northeastern United States, Lola was consistently, and in her words "almost inexplicably," drawn to work in schools that were extraordinarily culturally dissimilar from her own. She confessed she felt like a teacher in "one of those inspirational teacher films," conveying a romanticized vision of both teaching and herself. This romanticized identity seemed well entrenched, but her assumptions were largely un-interrogated until she entered the classroom as a teacher.

Lola's disequilibrium. Deeply committed to social justice and racial equity, Lola's disequilibrium emerged from the chasm between her idealized identity as a high-quality White teacher on one hand, and the contexts, norms, and constraints of the culturally diverse communities to which she is drawn, on the other hand. Lola sought teaching positions in places where her idealized identity was in harmony with the figured world of the school, where she felt she was seen the way she wanted to be seen. When she felt faculty, administration, 
parents, or students at the school did not see or treat her as a professional, highly qualified and racially savvy, White teacher, Lola experienced disequilibrium. Lola's response to disequilibrium was drastic in scale; she left teaching positions entirely, thus contributing to the erratic nature of her career path.

Lola was excited about her first job. She felt she belonged among the young and energetic faculty. Yet, there were considerable schoolwide behavior issues. Administrators expected Lola to use the school's system of merits and demerits, which she saw as "an art" that would take time to master. She described her ensuing struggle with students' behavior as "hard," "humiliating," and "torture." She broke into tears the day she handed out midterm grades because so many students were failing. She attributed the failures to students' bad behavior and her lack of control, which she fundamentally equated to the cultural differences between her and her students combined with what she perceived as insufficient classroom management preparation. Having invested much of her emotional well-being in teaching, but unwilling to compromise her expectations, Lola worried about the absence of balance in her life; she experienced long work days with very little spiritual or emotional respite. She conveyed a literal sense of disequilibrium in her life and left her first job for a position at a school further south, largely in an attempt to return to balance.

Lola's second school was a secondary-level charter boarding school in a mid-Atlantic city serving predominately African American students. Here again, Lola experienced disequilibrium, which emerged from the tension between her identity and the nearly exclusively historically Black figured world of the school. She regarded racial tension as the "elephant in the room" and the professional culture as "toxic." By the first parent-teacher conference, many students were failing her class, and parents arrived upset, with a few implying that Lola was unable to reach their children. She understood the implication to be that she did not know how to teach Black children. Lola began to question her efficacy as a White teacher of Black students. She reported feeling alienated from the school culture, and explained, "It's like, 'no, you're not a part of that culture, Lola, and you can love it all you want but you're not one of them ... and maybe you're not even wanted there'." Over time, she tempered these sentiments. This expressed disillusionment reveals Lola's initial steps in deconstructing 
her largely uninformed assumptions about the figured world of this school and her place within it.

It was at Lola's third school-a racially, linguistically, and socioeconomically diverse urban school in the mid-Atlantic region-that Lola gained control of the disequilibrium. She credits this in part to teaching skills she picked up at previous forsaken positions. From an observer's view, however, her new sense of stability was grounded in the acceptance she gained from the students, parents, faculty, and administration with whom she deeply identified with from the outset.

Riley: Implosion under the weight of a top-heavy system. The case of Riley Miller illustrates how one teacher failed to "refigure herself" into a teaching world at odds with her professional goals. In fact, one might say, she "resisted the pressure to refigure herself" in this world. From the outset, Riley believed teachers should help students develop socially, academically, and emotionally. In trying to enact those ideals as a student teacher, Riley quickly came to appreciate the range of needs her students presented, and the challenge teachers faced trying to meet them. Riley was hired as a fourth-grade teacher at a suburban school in the Northeast where she taught for 3 years. The supportive school environment closely matched her professional goals, and she took advantage of opportunities to attend professional development courses. Riley was able to figure herself as a teacher and thrive in an environment where her professional goals were nourished. In this context, it would seem as if Riley figured herself into the world of teaching without much effort, but in fact, she worked diligently to meet the high expectations set for teachers at the school.

Riley's disequilibrium. After passing the hallmark third year of teaching when many leave the profession (Henke et al., 2000), and exhibiting rich and promising practice, a personal situation compelled Riley to leave the position at which she was roundly praised for her professionalism. She moved across the country and was hired at a charter school in a suburban area in the Southwest.

Early that fall, the new principal held a school-wide meeting where she told all teachers that they were to use only direct instruction to increase standardized test scores. She also stated that anyone who was not on board should "get off the bus," a metaphor used for the 
school and direction it was taking. Teachers were also told that they were "easily replaceable" if they chose to leave. In response, Riley thought, "The independent part of me wanted to jump ship, or bus rather, at that very moment." This top-down administrative style offered a stark contrast to Riley's prior experience. Thus, Riley entered her fourth year immediately experiencing disequilibrium due to the limited sense of agency Riley felt at her new school. She had come from a school where teachers were valued as intellectuals to a new school where teachers were voiceless and considered easy to replace.

After nearly a full academic year in this new teaching context, Riley was present when the principal made an offensive remark about an interracial family. Riley spoke up against this and what ensued was a confrontation that pitted the principal against both the parent and $\mathrm{Ri}$ ley. This experience served as the final straw for Riley, who chose not work at a school where she perceived the leader to be disrespectful, setting a tone of toxicity, which permeated the school environment.

Riley had also been "positioned" in such a way that she was not "engaged in self-making, but rather [was] limited to varying degrees of accepting, rejecting, or negotiating the [identity] being offered to [her]" (Urrieta, 2007, p. 111). Riley chose not to refigure herself, or to compromise her developed identity in this new world. Lacking any sense of agency and stalled in her professional growth, she realized that this figured world was not a space that welcomed her teaching or met her expectations in any way. This new school was clearly a contact zone, defined as "social spaces where cultures meet, clash, and grapple with each other, often in contexts of highly asymmetrical relations of power" (Pratt, 1992, p. 1). The increased disequilibrium prompted Riley to leave the school and teaching entirely.

Elsie: Pulled apart by centrifugal force. Elsie's narrative is most stark, a story of leaving teaching not by her own choice. Elsie's teaching career reflects both a lack of professional agency as well as an inability to negotiate critical factors that exemplify and support quality teaching.

Elsie Reynolds was an exceptionally adept student herself, and initially came to the profession with high expectations for herself and students, reflecting her own positive learning experiences throughout her "apprenticeship of observation" (Lortie, 1975). In contrast, social 
interactions were difficult for Elsie, whereby she saw herself as "unpopular" and "on the outside" in school environments, prior to entering the teaching profession.

Elsie took a position in the school she completed student teaching, providing her with some expectations for the school world she was entering as a teacher. However, her classroom was physically isolated from others in her department, such that regular and substantive guidance was limited.

Elsie's disequilibrium. Elsie is a failed teacher, failed by the institution that did not support her through her first year in the classroom, and herself failing to integrate into the school and profession successfully. Contact between Elsie, her students, colleagues, her mentor, and the administration was characterized by a lack of clear and direct communication or action to appropriately identify and address disequilibrium. Reticence to address obvious and growing problems existed on the part of all participants in this narrative of learning to teach, resulting in confusion, frustration, and ultimately the loss of a very bright and motivated teacher. Elsie experienced disequilibrium on two fronts: in developing positive, productive personal relationships, and with developing and maintaining an image of effective teaching and learning.

Elsie came to the school with high expectations for herself and her students. As a teacher, however, she was faced with what she perceived as low student performance and motivation in a private, college preparatory program. Elsie questioned her earlier expectations and, over time, lowered standards and expectations for students.

Interpersonal interactions continued to be difficult for Elsie with colleagues who described her as "acerbic" and reported simmering tensions with teachers in neighboring classrooms that were never addressed or acknowledged officially. Significant to her classroom practice were pervasive difficulties with classroom management, reflecting different sorts of relationship challenges. Elsie and her colleagues described her approach as "lenient" and "easy on" students, who, in turn, were noisy, disruptive, and disrespectful in her classes. Elsie never understood classroom management as developing a respectful and collaborative working relationship with students.

Administration was inert in acting on her classroom struggles. Officially observed twice during the year, Elsie reported that she was 
never provided feedback from these observations. Her mentor unapologetically noted, "You often times have to seek some support yourself." Increasingly embarrassed by what she recognized as ineffective teaching and socially unequipped to seek counsel or support, Elsie maintained her isolation, without pressing for feedback or support

In the spring, the principal informed Elsie he would not renew her contract, although no specific reason was offered. Shaken and surprised, Elsie completed the academic year dramatically shutting out both judgment and support by covering the wall of windows that faced into the hallway from her classroom with butcher paper. She never pressed to find out exactly what concerns contributed to her release, and in keeping with her previous pattern of inaction, Elsie withdrew from the world of teaching entirely.

\section{Cross-Case Analysis: Thematic Consistencies and Variations}

We used cross-case analysis to identify themes, uncover contradictions, and draw connections between the cases. Here again, we framed our emerging understandings within the theory of figured worlds by continually checking how graduates resembled or differed from one another in the manner they expressed their identity, how they were received and interacted with the world in which they were acting, and figured themselves within the context of the school worlds.

Broadly speaking, in the cases of Elizabeth and Lola, the teachers encountered disequilibrium, but managed to address this in a way that made it possible to stay in teaching. In a profound way, these represent two cases of successful retention. In the other two cases, Riley and Elsie, both were fundamentally challenged by the disequilibrium they faced, and subsequently, both teachers left the profession. To offer theorized explanations as to why this occurred, we first developed assertions derived from the local detail of the individual case that helped explain teaching practice coupled with career decisions. Next, themes were identified deductively and iteratively by examining general linkages, analytic categories, and variations from the withincase analysis. The emergent themes described graduates' capacity and capability in three aspects: figuring the self/figuring school worlds, agency, and collaborative capacity. Below, we describe each of these themes in turn, including how they played out between and among the four cases. 
Figuring the self. As stated earlier, the research of Sloan (2006), C. Robinson (2007), and Ma and Singer-Gabella (2011) addresses the manner in which teachers and teacher candidates were able to "figure themselves," including their ability to improvise when their figured world "bump[ed] up against" their identity in unforeseen ways. In each of the cases considered here, it becomes clear that the teachers' "figuring" impacted the social worlds in which their actions were embedded, which in turn impacted how the teacher figured herself. The four teachers presented striking similarities and contrasts in their capacity to establish a well-developed, or deeply engrained, teaching identity prior to, during, and post-graduation.

The two teachers who expressed deeply held expectations, Riley and Lola, had a challenging time figuring themselves into school settings that did not match their richly developed and deeply entrenched teaching identities. In addition, because Lola in particular presented a dogmatic ascription to her teaching identity, she portrayed a type of "Goldilocks Syndrome." There were many schools that would not quite work and a very limited number of schools that fit just right.

Interestingly, the two teachers who displayed the least entrenched teaching identities, Elizabeth and Elsie, appeared to have the most divergent experiences in terms of career longevity. Elizabeth came into the career having had positive experiences with tutoring urban youth in the past but had not created a fixed set of expectations about her role as a teacher or about the type of school community in which her identity could flourish. In Elizabeth's case, this fluid perspective served her well as a starting point in her career, as she began building a teacher identity over time.

Elsie began her career with little specificity about what good teaching looks like in practice, focusing instead on what a good student might look like, and comparing this with herself. Over time, however, with little support or guidance from within the school, Elsie did not strengthen or deepen her understanding of what constitutes good teaching in ways that Elizabeth demonstrated in the same period. In Elsie's case, her teaching identity was not sufficient to uphold convictions about teaching when this was challenged by her experience in her school context. Exacerbated by weak interpersonal skills and the lack of direct mentoring to address problems in practice, she felt little exchange or change within the school in response to her actions there. In fact, she avoided the very interactions that might have offered her 
support in finding her way in her teaching world. In a school setting that was neither proactive nor supportively reactive to the challenges that were obvious in Elsie's classroom, she experienced an unraveling of practice and confusion about her place in the school and the profession. Such a setting is in complete opposition to the sociocultural interactions Wenger (1998) indicates are necessary to learning in a community of practice, whereby "the right people are at the right place in the right kind of relation to make something happen” (p. 232).

Figuring school worlds. These teachers were simultaneously challenged with figuring themselves and figuring an existing school world. Holland et al. (1998) write of the "codevelopment" that occurs as "identities are worked and reworked on the social landscape" (p. 270), underscoring the interconnections of an evolving self and a particular figured world. In a very pragmatic way, they embodied the ways of speaking, acting, and interacting their interpretation of "teacher" within the social and cultural construct of a figured world of their school environment.

Holland et al. (1998) states that each figured world is a

socially and culturally constructed realm of interpretation in which particular characters and actors are recognized, significance is assigned to certain acts, and particular outcomes are valued over others. Each is a simplified world populated by a set of agents ... who engage in a limited range of meaningful acts or changes of state ... as moved by a specific set of forces. (p. 52)

Each teacher enacted their conception of effective teacher within a realm construed and revised by their own participation in the act of teaching. The figured world and the interpretation of place and power in this sphere are continuously under revision as decisions and actions are played out. Career decisions are considered and adopted, as a result of the understandings of whether and how teachers can negotiate, without overwhelming disequilibrium, their school world to the satisfaction of their teacher selves and those in power around them. As with the development of identity, this is an "open-ended, transactional" process (Fecho et al., 2005, p. 177) that occurs on the individual and collective level. 
These four teachers displayed marked contrasts and similarities in their capacity to accurately and realistically figure school worlds. From the beginning, both Elizabeth and Lola expressed an avowed commitment to work in urban contexts. To some degree, they were both familiar with the challenges and possibilities of working in these contexts. However, in Elizabeth's case, she stayed in the same school. In sharp contrast, Lola relocated from one school to another in search of the best fit. What explains this difference?

We theorize that the difference has much to do with both the accuracy of their figuring, and the experiences (or lack thereof), which underlie their expectations as teachers and about teaching. Lola expressed a deep commitment to work in a city school but only maintained a surface familiarity with actual teaching life in the figured world of urban schools. Recall, she had an "almost inexplicable" draw to work in urban communities and one that was clearly not rooted in actual experience. So, although Lola claimed to know what she wanted, she lacked the experience to identify "it" precisely or describe what "it" was. Again, like Goldilocks looking for the most comfortable chair, she only knew it was right when she experienced it.

Meanwhile, Elizabeth had a much more accurate understanding of the urban context in which she ultimately worked. She grew up in a community in close proximity to her future school district, and as such, she had an understanding informed by a bit more awareness of her students' lives. Despite some of the contrasts that define the finer levels of granularity between Lola and Elizabeth, both were relatively successful in figuring the world in which they wanted to teach, though Lola required more time before she figured the world with enough precision to be successful.

In contrast to Elizabeth and Lola, Riley and Elsie both struggled when they found themselves in school contexts that diverged sharply from the school worlds in which they assumed they would be working. The reality of the figured world of the school in which they found themselves seemed relatively fixed and unwilling to be shaped by exchanges with these teachers. Elsie set rigid parameters in her search for a school that met her outlined criteria. She took a job at a private, Catholic, college preparatory school, as intended. Yet the teaching environment within the school left her physically isolated from colleagues and out of step with students. With both Elsie and the school 
community tacitly avoiding any meaningful communication or action to ameliorate obstacles encountered in traversing this figured world, Elsie was unable to have a truly positive effect on students and school.

Riley came to her new position in the Southwest not even having so much as toured the school or met any of the administration in person. Her misjudgment of this new school, with its top-down managerial approach and scripted curriculum, was only made plainer when contrasted with the school world she previously enjoyed. Riley expressed through interviews something of a "join or leave" mentality operating within this school. The constricting environments experienced by Riley and Elsie, which in many ways pushed back against these teachers' efforts to retool their world, also made it difficult for both to refigure the world. Coupled with their individual traits-in Riley's case her deep adherence to a well-developed teaching identity and in Elsie's case her own limited social proficiencies-an exit from these figured worlds seem all but inevitable.

Agency. In each of our four cases, the graduates recognized their capacity for reshaping their identities as teachers, or capacity for impacting the figured world of the school, to differing degrees. In other words, each participant embodied different degrees of agency with regard to her work as a teacher. Holland et al. (1998) explain,

Human agency [is] the realized capacity of people to act upon their world ... That capacity is the power of people to act purposively and reflectively, in more or less complex interrelationships with one another, to reiterate and remake the world in which they live. (p. 42)

Agency is critical to understanding whether and how these four teachers responded to incidents of disequilibrium and to understanding how they emerged from this state. Fecho et al. (2005) note the benefit that comes with the ability to "appreciate the wobble for what it might tell us about ourselves and our ongoing practices ... find[ing] comfort in discomfort" (p. 179). For novice teachers, this includes an exploration of understanding disequilibrium for its centrifugal and centripetal tension, that is, the forces at work simultaneously to unify and destabilize the notion of individual identity (Fecho et al., 2005). 
Similarly, Tamir (2014) found that teachers from elite colleges persevere in schools where they see themselves as successful change agents in schools. Horrowitz (2014) likewise concluded that the interplay between a teachers identity and agency was key for teachers to continue what she describes as an ongoing process of "choosing to teach" as valued and contributing members of the school as a whole.

In the case of Elizabeth and to a lesser extent, Lola, these two teachers demonstrated agency in response to disequilibrium. Elizabeth's case is noteworthy in the sense that, despite extraordinary hardships, she perseveres in the same school year after year. Located in a neighborhood beset with gang violence, the school in which Elizabeth worked failed to graduate $40 \%$ of the students in 4 years. At the outset, the school lacked basic classroom amenities and crucial support systems needed to improve teachers' practice. Elizabeth was provided limited mentoring, no support staff, and few opportunities for professional growth. Determined and optimistic, Elizabeth sought out and participated in many professional development opportunities beyond her school to enrich her practice claiming, "I'll take what I can get." Elizabeth's successful stabilization was a consequence of varied factors, including her ability to navigate school culture, her resourcefulness, her commitment to continual growth as an educator, and above all else, her commitment to providing students with a superior education. It can be said, therefore, that Elizabeth recognized the significant power she could leverage to adjust her circumstances.

To a lesser extent, this attribute of agency existed with Lola as well but largely in the sense that Lola recognized she had the power to affect her own destiny. The manner in which this manifested in her teaching career, however, was striking. Lola realized that if the figured world of a particular school did not fit, she could at least demonstrate the agency to make a life change to realize her vision. In these moments of disequilibrium, some aspects of identity are clarified and strengthened, or as Urrieta (2007) notes the "clash of figured worlds" can lead to empowerment and definition of identity. However, it does well to remember that the short duration of her tenure at each school was just as jolting for the school as if she were to leave the profession altogether (Ingersoll, 2003). So, while Elizabeth made deliberate choices and mobilized resources to shape the world in which she found herself, positively impacting both herself and the figured world 
of the school, Lola left the school. Both of these are manifestations of agency, yet one model is mutually beneficial to the school and to the individual, while the other model puts the individual's needs and identity development above that of the school.

Similar to Lola, Riley had a strong sense of agency that was intricately tied to her identity as a teacher. She acted "purposefully and reflectively" to meet her professional goals. Although her agency was seemingly manifested in opposing ways, her actions were motivated by her commitment to students in both worlds. The first teaching context that matched Riley's goals empowered her to become the best teacher possible-to secure her position in a world she regarded highly. When the second teaching context worked to strip away Riley's dignity as a teacher by dictating her practice, she exercised her sense of agency by leaving. In both instances, the teachers exhibited agency in their own interests, making choices that lay within the boundaries they perceived to be acceptable and healthy to their teaching identity.

At the other end of the spectrum was Elsie, who displayed limited evidence of agency when it came to affecting her world. She perceived the school as a place where she could not have agency in her teaching. In fact, there was a lack of responsive negotiation on the part of all actors in this world-Elsie, mentors, and administrators. Horrowitz (2014) suggests that true agency, or the "ability to function effectively and creatively in an environment," requires being "sufficiently immersed in the context to operate fluently in it" (p. 77). Elsie remained on the periphery of her figured world, and other stakeholders did little to draw her in, interact with her, encourage or support her toward effective agency.

Although Elsie shared many characteristics and challenges with the other teachers described here, she was unique in demonstrating a lack of agency to address the disequilibrium in her professional life. Sloan (2006) notes,

The degree to which a person can be said to experience and exhibit agency depends on the ways he or she identifies with a given figured world and on their level of expertise within that figured world. (p. 141) 
With little power or agency functioning as a stabilizing force, Elsie succumbed to what Fecho et al. (2005) identify as "centripetal and centrifugal tension" (p. 178), wherein the disequilibrium fractured and further muddled Elsie's understanding of her figured world.

Collaborative capacity. Much has been written about the centrality of professional learning communities and networks for ongoing collaboration in supporting the health, well-being, and perseverance for teachers (Baker-Doyle, 2011; Dika \& Singh, 2002; Gallucci, 2008; Hargreaves \& Fullan, 2012; Putnam, 2001, 2015; Qian, Youngs, \& Frank, 2013; Spillane et al., 2001). Our cases bear out this critical feature in the figured world of teaching, as well. As Urrieta (2007) highlights, "through participation in figured worlds people can reconceptualize who they are or shift who they understand themselves to be" (p. 120). The power of the network to provide a source for learning, stabilization, and socialization into the figured world of schools cannot be overstated. Two cases described here indicate the potential that exists when a strong professional network is present.

Elizabeth, in part, derived her strong sense of agency from the strength and clarity that emerged from being a member of a collaborative network. Feedback, support, and validation were three key aspects missing from Elizabeth's experiences with the leadership at her school, though developed over time from outside of her teaching environment. Professional development opportunities initially acted as a large part of her emerging network. She highlighted, "I always left the day feeling like what I do here is important. It was like a professional forum where we could validate ourselves for doing great things with our students' learning." Over time, Elizabeth strengthened her networking abilities and eventually built an extensive and regenerating professional network. She became adept at working with like-minded colleagues within her school. These teachers "figured their worlds" much in the same way Elizabeth looked to colleagues for emotional support, ideas on improving her teaching, and resources. Moreover, as a group this professional community worked together to reshape and refigure the world of the school, highlighting the reciprocal and iterative exchanges, systems-learning, and organization capacity building within what Gallucci (2008) refers to as the "Vygotsky Space." Drawing from sociocultural theory, Gallucci contends that analyzing exchanges within the Vygotsky Space allows researchers to acknowledge 
the ways in which "individual development contributes to collective (cultural) change" (p. 548). In other words, by contributing to the professional communities within the school, Elizabeth's collaborative capacity simultaneously reshaped both her individual figuring of the school, and the school community in toto.

Elizabeth's commitment to building relationships is consistent with the assertion by Urrieta, Martin, and Robinson (2011) that "[i]n figured worlds people learn to recognize each other as actors, sometimes with strong emotional attachments, where certain outcomes are valued over others, and where acts have more significance over others" (p. 494). In this case, Elizabeth worked to collaborate with those committed to providing exemplary learning opportunities for students.

Similarly, Riley's first job provided many opportunities to collaborate with colleagues, of which she took full advantage. Aware that having a strong network was a key to professional growth, Riley reached out for help and asked questions to guide her with instructional and student-related decisions. In an interview, her principal spoke about Riley's commitment to professional collaboration as a means to promote her ongoing learning and growth:

[Riley] spent a good deal of the summer coming in and [working] with her colleagues ... She's probably the first one to come in to ask for help, which I think is great ... [S]he learns from other people, yet, she also will make things her own. She's incredibly dedicated.

The highly regarded school matched Riley's expectations about teaching where a genuinely supportive learning environment balanced high standards and demands for teachers and students alike. Teachers were expected to know their students as learners and individuals, and challenged to continually deepen their practice through collaborative efforts representing an example of collective knowledge and practice emerging from "in between" actors (as cited in Spillane et al., 2001, p. 25). In this context, she devoted considerable time and effort to her ongoing professional growth and her students' wellbeing, during her 3-year tenure at this school.

Perhaps what is more telling, however, are outcomes when opportunities for collaboration and networking were lacking. Lola and Riley each experienced the realization that without a rich and supportive 
network of professional colleagues in their work world, their lives as teachers were simply not as rich. In Lola's case, she moved from her first year as a teacher in a northeastern school where the building leader provided ample opportunities for networking and collaboration. He worked hard with the young and energetic faculty at the school to address school-wide behavior problems. He solicited his faculty suggestions and feedback ahead of implementing a coherent, school-wide system of student management. He made regular classroom visits and provided thoughtful and substantive feedback to Lola. His leadership style created a culture of networking and collaboration within the school and this culture permeated to faculty. Lola talked at length about the importance of creating professional ties, drawing both strength and ideas from professional networks, and the critical aspect of collegiality to the well-being of a school. It is significant to note, however, that this was not sufficient in and of itself for Lola to remain in this position. As noted above, her struggle to be an effective White teacher in multicultural classrooms overshadowed this positive support.

However, Lola and Riley were shocked to move from a culture of collaboration and networking to school cultures, which they referred to as "unprofessional," "insulting," "toxic," "racist," and "hierarchical." For these teachers, the marked contradiction between teaching settings was dehumanizing and demoralizing. Both teachers felt stripped of their fledgling sense of agency and professionalism. Although torn by a growing commitment to the children in their schools, these teachers felt stifled, untrusted, and to some extent ignored in this de-professionalized atmosphere. Lola and Riley decided within a year to leave their respective schools. For Lola, her third school environment was one that did offer professional connections to colleagues through common planning and committee work, as well as networking and professional development opportunities outside of the school setting. In Riley's case, however, there would be no immediate or foreseeable return to classroom teaching.

Finally, Elsie is notable for remaining on the periphery of the school community, lacking support from peers or administration and unable to mediate a network of personal or professional connections from a position of weak social skills. She recognized her isolation saying, "a lot of the time I feel like I'm alone ... and that's frustrating." Her 
mentor, in turn, ignored these difficulties instead explaining, "I'd say she was prepared, but it's the personality of a new teacher with a class ... Sometimes it just depends on the person; how they interact. And I think that's where the big difficulty came in." Elsie stayed at the margins of the figured world, and did not seek to develop collaborative interactions inside or outside the school. Administration and colleagues took note of the devolving classroom experience without interceding. This stalemate resulted in a negative learning environment for students and the novice teacher, ending with the eventual removal of Elsie from the community.

\section{Implications}

The experiences of these four teachers suggest that the manner in which they are able to figure and refigure themselves into the everevolving teaching world, and the interactions and responses enacted by the figured worlds they experienced, were closely connected to teachers' career trajectories. Each teacher's career path was a complicated amalgam of factors that had unique significance to the individual and could not be simplified or generalized to singular aspects as context, autonomy, school characteristics, and so forth. Successful teachers have very different approaches and strategies to figure themselves with and into the complex world of teaching. Furthermore, it is not a matter of either figuring oneself into a world of teaching (a particular teaching context) or figuring the teaching world (addressing standards and expectations of the profession) but the ability to simultaneously address and make continuous adjustments to both threads to be an effective teacher. Recognizing this complexity, it is necessary to anticipate and provide support for the inevitable disequilibrium new teachers experience. To that end, we outline three implications of our study for teacher preparation, school administrators, and the broader world of education policy.

First, in teacher preparation, before the onset of the teaching career, it would benefit teacher candidates to explicitly address how each school is a unique teaching world to be understood and negotiated, how their work impacts the context of the school, and how culture shapes one's experiences as a teacher. Many programs currently 
ask teacher candidates to consider and reflect on the development of classroom environment, student demographics, and community characteristics with a focus on the impact of a positive learning environment for pupil outcomes. However, there is benefit in considering these characteristics explicitly in light of teacher experience, particularly as they might influence the early years of learning to teach. There is evidence that individuals (in this case, teachers) differ in their tolerance for disequilibrium that requires such intentional consideration (Fecho et al., 2005). For example, this was the case for Elizabeth who addressed her difficulties, in contrast to Elsie who became paralyzed by challenges. Anticipating such tension and considering one's own ability to be flexible and resilient provides the opportunity to judge compatible work environments and how best to approach challenging conditions. Similarly, analyzing school structure and environment in terms of philosophy, protocols, administrative style, and teacher autonomy, including the schools' responsiveness and treatment of teachers as professionals-factors that may cause significant disequilibrium in the teaching world-would allow for acknowledgment of the tension, learning opportunities, and informed decisions made in the face of disequilibrium.

The goal for teacher preparation is to provide a foundation for persistence despite challenges, potential setbacks, or failure. Furthermore, awareness of how context, social interactions, and agency influence growth, assist in appropriately addressing challenges, and making thoughtful choices that further (rather than hinder) professional growth keep novice teachers in classrooms and avoid costly moves from school to school, or away from education through choice or failure. These changes may increase pre-service and novice teachers' accurate understanding of their own expectations, prompt action and innovation in responding to differences between their own capacities and work expectations, and prevent the emotional burnout that comes with recognition that expectations were unrealized or unrealistic.

It is clear from these cases, however, that teacher preparation alone cannot fully ready the novice teacher for navigating a particular institution in which they find employment. While the preparation program may begin the work of learning to address disequilibrium, it is within a particular context and in the act of teaching that one determines 
when it is best to bend in the wind, stand strong in a storm-or in one way or another-move out of the tempest. A second implication of this study, then, is that principals and administrators are critical to setting tone and expectations, as well as determining the level of support provided (Boyd et al., 2011; Ingersoll \& Kralik, 2004). However, principals are not currently necessarily an integral part of induction and mentoring programs that initiate the novice teacher to the school environment (Spillane et al., 2001; Wood, 2005). Yet, within the new teacher evaluation systems being implemented around the country, the principal's role as instructional leader and evaluator of teacher effectiveness is increasing. Because teachers frequently cite a perceived lack of administrative support as a key factor in decisions to leave schools and the profession (Ingersoll \& Kralik, 2004; Ladd, 2011; Richards, 2007, V. Robinson, 2007), a more connected administration and teaching staff, inspired by these new systems, could provide principals with increased opportunities to meaningfully interact with, support, and ultimately retain high-quality educators. Teacher attrition has significant financial costs not only in lost training and rehiring expenses but also in terms of developing and maintaining "organizational stability, coherence, and morale throughout the institution" (Smith \& Ingersoll, 2004, p. 686). In addition to administrative support aimed at curbing attrition, mentoring support and ongoing professional development should be intentionally differentiated for new teachers to address varying needs (D’Souza, 2014). Such support would stand in contrast to support needed for established, veteran educators who negotiate the figured world of our profession, one that is in constant flux and reform. All teachers, however, rely on administrative commitment and involvement to develop a productive, professional environment that understands the challenges of guiding teachers through their career trajectory.

Our final implication connects the school experience to broader policy issues. Fecho et al. (2005) refer to "externally imposed wobble of reform" that poses challenges to all schools and teachers. Education reforms and mandates that attempt to simplify and manage all elements of education-from what a student should look like and how teachers should teach-are detrimental to the process of teachers figuring themselves into the world of teaching, in ignoring the complexity and impossibility of such micro-management. Furthermore, while 
the focus of this study is on the experience of novice teachers, there is evidence that veteran teachers are leaving at a similar rate as novice teachers (Jacob et al., 2012), an indicator perhaps of the growing inability, or unwillingness to negotiate the disequilibrium from the multiple layers of imposed reforms that resonate through a school and classroom. Indeed, Jacob et al. (2012) refer to the "irreplaceables" as high performing teachers (both novice and veterans) lost to the education profession who might have been retained through attention to regular feedback and development, recognition of accomplishments and performance, opportunities for responsibility and advancement, and availability of resources. Implementation of these strategies, however, would require a major shift in priorities that currently exist. For instance, new teacher evaluation systems are seeking to meet the needs of teachers as described above (e.g., regular feedback and development, recognition of accomplishments and performance), though it is yet to be seen whether the well-intentioned goals are likely to be met as they are currently being implemented. Thorius and Scribner (2013) note that in an age of constant educational reform, schools have "underinvested" (p. 135) in preparing teachers for change and the complex practice of teaching, ignoring "cognitive, emotional, and dispositional dimensions ... necessary for systemic improvement" ( $p$. 135), which are highlighted in this study as critical factors in the process of learning to teach in a figured world.

Numerous theorists have recognized the critical role social and professional capital play in the development of positive, effective working environments in schools (Baker-Doyle, 2011; Dika \& Singh, 2002; Gallucci, 2008; Maier \& Youngs, 2009; Penuel, Riel, Krause, \& Frank, 2009; Putnam, 2001, 2015; Qian et al., 2013; Spillane et al., 2001). Hargreaves and Fullan (2012) call for a change in perspective at a national level. They describe school environments in which professional capital-integration of individual talent (teachers) and collaborative social culture (the school)-is the currency of effective teaching. Professional capital is, however, dependent on long-term, ongoing systematic investment into students and teachers. They note,

Consider what happens when a talented individual enters a school low on social capital. Although it is possible to make a difference through heroic effort, eventually the 
overwhelming likelihood is that the person will leave or burn out in the process ... Now consider the reverse: A teacher who is low on human capital and has poor initial confidence or undeveloped skills enters a highly collaborative school. Chances are high that this teacher will be socialized into greater teamwork and receive the assistance, support, ideas, and feedback to help him or her improve. (p. 4)

Hargreaves and Fullan (2012) assert that although achievement and evidence are indeed important educational outcomes,

The view that what schools should be about are performance, scores and results to excess has lost sight of all the other things that characterize teaching, that teachers bring to their work, and that keep them and their children motivated. (pp. 10-11)

Alternatively, true professional expertise can be honed to the benefit of students, and in support of retention of teachers, in a system where both the complexity of teaching and ongoing disequilibrium are acknowledged.

\section{Conclusion}

In our current reform era with sweeping changes and major initiatives being implemented, the existing retention issues in the teaching profession are likely to become more complicated and require even more nuanced understandings to meaningfully support and retain highquality teachers. This research suggests that simple policy solutions focusing on one aspect of teaching or retention are unlikely to be comprehensive and powerful enough to truly impact how teachers figure the world of teaching and in turn, figure themselves into that world to be effective educators. For teachers to be successfully recruited and retained, they need to be prepared for the disequilibrium of learning to teach, and to work in an environment where they can find the skills and resources to overcome dissonance, as well as learn from it. Policy makers, administrators, and teacher educators must also understand 
the nature of this disequilibrium to help construct and sustain a world of teaching where high-quality teachers can thrive.

Analogous to Spillane et al.'s (2001) contention that leadership decisions are "stretched over multiple actors, materials and contexts," teachers' decisions to stay or leave must be similarly construed as stretched over these multiple actors and contexts. Rather than enacted by a single individual responding to a static situation, teachers' career decisions reflect the exchange of interpretations between actors and within a context. This suggests that it is long past time to abandon the notion of the silver bullet-or singular variables-that will stem attrition from schools and prevent teachers from leaving. In contrast, education stakeholders must design and enact policies that acknowledge the complex interplay between novice teachers and the contexts of schools.

Working from this lens forces education researchers to rebuff education policies that treat teachers and their career decisions as separate, personal, or private decisions that happen in a vacuum without the continuous interaction of the school stage. For example, valueadded policies that treat teachers as the single lever acting in a vacuum on student achievement must be reexamined. Healthy policies would recognize the iterative exchange between teachers and the worlds in which they work. In that vein, it is clear that student achievement data on high stakes tests are not outcomes of specific classroom teachers. Rather, they are outcome measures reflective of the entire school community including students, teachers, parents, and distributed leaders such as mentors, coaches, curriculum leaders, and top administration, as well as societal issues such as poverty and immigration, for example. Similarly, education policies must foster the understanding that teacher development includes advancing teachers' agency, and highlighting the key role of administration in fostering and cultivating teacher professionalism and voice (Harley, 2009).

Education policy might acknowledge that teachers are not their value-added score but complex and learning actors on a complex and evolving stage. These types of policy frameworks acknowledge the simple fact that teachers' career decisions are not reflective of a private and individual decision but rather reflect a confluence of factors that call the actions of many agents into investigation. 
Conflicting Interests The authors declared no potential conflicts of interest with respect to the research, authorship, and/or publication of this article.

Funding This work was supported in part by a grant from the Carnegie Corporation and Ford Foundation.

\section{References}

Ayres, L., Kavanaugh, K., \& Knafl, K. A. (2003). Within-case and across-case approaches to qualitative data analysis. Qualitative Health Research, 13, 871-883.

Baker-Doyle, K. J. (2011). The networked teacher: How new teachers build social networks for professional support. New York, NY: Teachers College Press.

Bakhtin, M. (1981). The dialogic imagination: Four essays by M.M. Bakhtin (M. E. Holquist, Ed. \& C. Emerson \& M. Holquist, Trans.). Austin: University of Texas Press.

Bartlett, L. (2007). To seem and to feel: Situated identities and literacy practices. The Teachers College Record, 109(1), 51-69.

Blackburn, M. V. (2002). Disrupting the (hetero) normative: Exploring literacy performances and identity work with queer youth. Journal of Adolescent \& Adult Literacy, 46, 312-324.

Boaler, J., \& Greeno, J. G. (2000). Identity, agency and knowing in mathematical worlds. In J. Boaler (Ed.), Multiple perspectives on mathematics teaching and learning (pp. 171-200). Westport, CT: Ablex.

Borman, G. D., \& Dowling, N. M. (2008). Teacher attrition and retention: A metaanalytic and narrative review of the research. Review of Educational Research, 78, 367-409.

Boyd, D., Grossman, P., Ing, M., Lankford, H., Loeb, S., \& Wyckoff, J. (2011). The influence of school administrators on teacher retention decisions. American Educational Research Journal, 48, 303-333.

Boyd, D., Lankford, H., Loeb, S., \& Wyckoff, J. (2005). Explaining the short careers of high-achieving teachers in schools with low-performing students. American Economic Review, 95, 166-171.

Cochran-Smith, M., McQuillan, P., Mitchell, K., Terrell, D.G., Barnatt, J., D’Souza, L., Jong, C., Shakman, K., Lam, K., \& Gleeson, A.M. (2012). A longitudinal study of teaching practice and early career decisions: A cautionary tale. American Educational Research Journal, 49(5), 844-880.

Cochran-Smith, M., \& Villegas, A. M. (2015). Framing teacher preparation research: An overview of the field, Part I. Journal of Teacher Education, 66, 7-20.

Cuddapah, J.L., \& Clayton, C.D. (2011). Using Wenger's communities of practice to explore a new teacher cohort. Journal of Teacher Education, 62(1), 62-75. 
Dagenais, D., Day, E., \& Toohey, K. (2006). A multilingual child's literacy practices and contrasting identities in the figured worlds of French immersion classrooms. International Journal of Bilingual Education and Bilingualism, 9, 205-218.

Darling-Hammond, L. (2010). The flat world and education. New York, NY: Teachers College Press.

Darling-Hammond, L. (2013). Getting teacher evaluation right: What really matters for effectiveness and improvement. New York, NY: Teachers College Press.

DeAngelis, K. J., Wall, A. F., \& Che, J. (2013). The impact of preservice preparation and early career support on novice teachers' career intentions and decisions. Journal of Teacher Education, 64, 338-355.

Diez, M. (2010). It's complicated: Unpacking the flow of teacher education's impact on student learning. Journal of Teacher Education, 61, 441-450.

Dika, S. L., \& Singh, K. (2002). Applications of social capital in educational literature: A critical synthesis. Review of Educational Research, 72, 31-6o.

Donaldson, M., \& Johnson, S. M. (2010). The price of misassignment: The role of teaching assignments in Teach For America teachers' exit from low-income schools and the teaching profession. Educational Evaluation and Policy Analysis, 32, 299-323.

D'Souza, L.A. (2014). Bridging the gap for beginning teachers: Researcher as mentor. International Journal of Mentoring and Coaching in Education, 3(2), 171-187.

Fecho, B., Graham, P., \& Hudson-Ross, S. (2005). Appreciating the wobble: Teacher research, professional development, and figured worlds. English Education, 37, 174-199.

Freedman, S. W., \& Appleman, D. (2009). "In it for the long haul": How teacher education can contribute to teacher retention in high-poverty, urban schools. Journal of Teacher Education, 6o, 323-337.

Furlong, J., Cochran-Smith, M., \& Brennan, M. (2013). Policy and politics in teacher education: International perspectives. New York,, NY: Routledge.

Gallucci, C. (2008). Districtwide instructional reform: Using sociocultural theory to link professional learning to organizational support. American Journal of Education, 114, 541-581.

George, A. L., \& Bennett, A. (2005). Case studies and theory development in the social sciences. Cambridge, MA: MIT Press.

Goldhaber, D., Gross, B., \& Player, D. (2011). Teacher career paths, teacher quality and persistence on the classroom: Are public schools keeping their best? Journal of Policy Analysis and Management, 30, 57-87.

Goldhaber, D., \& Hansen, M. (2013). Is it just a bad class? Assessing the long-term stability of estimated teacher performance. Economica, 80, 589-612.

Guarino, C., Santibanez, L., \& Daley, G. (2006). Teacher recruitment and retention: A review of the recent empirical literature. Review of Educational Research, 76, 173-208. 
Hammerness, K. (2008). If you don't know where you are going, any path will do: The role of teachers' visions in teachers' career paths. The New Educator, 4 , 1-22.

Hammerness, K., Darling-Hammond, L., Bransford, J., Berliner, D., CochranSmith, M., McDonald, M., \& Zeichner, K. (2005). How teachers learn and develop. In L. Darling-Hammond \& J. Bransford (Eds.), Preparing teachers for a changing world: What teachers should learn and be able to do (pp. 358-389). San Francisco, CA: Jossey-Bass.

Hanushek, E. A., Kain, J. F., \& Rivkin, S. G. (2004). Why public schools lose teachers. Journal of Human Resources, 39, 326-354.

Hargreaves, A., \& Fullan, M. (2012). Professional capital: Transforming teaching in every school. New York, NY: Teachers College Press.

Hartley, D. (2009). Education policy, distributed leadership and socio-cultural theory. Educational Review, 61, 139-150.

Hatt, B. (2007). Street smarts vs. book smarts: The figured world of smartness in the lives of marginalized, urban youth. The Urban Review, 39, 145-166.

Henke, R., Chen, X., \& Geis, S. (2000). Progress through the teacher education pipeline: 1992-93 college graduates and elementary/secondary school teaching as of 1997 (Report, NCES 2000-152). Washington, DC: Office of Educational Research and Improvement, U.S. Department of Education.

Henry, G. T., Campbell, S. L., Thompson, C. L., Patriarca, L. A., Luterbach, K. J., Lys, D. B., \& Covington, V. M. (2013). The predictive validity of measures of teacher candidate programs and performance: Toward an evidence-based approach to teacher preparation. Journal of Teacher Education, 64, 439-453.

Hill, C. E., Knox, S., Thompson, B. J., Williams, E. N., Hess, S. A., \& Ladany, N. (2005). Consensual qualitative research: An update. Journal of Counseling Psychology, 52, 196-205.

Hill, C. E., Thompson, B. J., \& Williams, E. N. (1997). A guide to conducting consensual qualitative research. The Counseling Psychologist, 25, 517-572.

Holland, D., Lachtcotte, W., Skinner, D., \& Cain, C. (1998). Identity and agency in cultural worlds. Cambridge, MA: Harvard University Press.

Hong, J. Y. (2010). Pre-service and beginning teachers' professional identity and its relation to dropping out of the profession. Teaching and Teacher Education, 26, 1530-1543.

Hong, J. Y. (2012). Why do some beginning teachers leave the school, and others stay? Understanding teacher resilience through psychological lenses. Teachers and Teaching: Theory and Practice, 18, 417-440.

Horrowitz, B. (2014). Choosing to teach: Identity and agency among beginning teachers. In S. Feiman-Nemser, E. Tamir, \& K. Hammerness (Eds.), Inspiring teaching: Preparing teachers to succeed in mission-driven schools (pp. 75-102). Cambridge, MA: Harvard Education Press.

Ingersoll, R. (2003). Is there really a teacher shortage? (A Research Report Cosponsored by The Consortium for Policy Research in Education and The Center for the Study of Teaching and Policy). University of Pennsylvania: GSE 
Publications. Retrieved from http://repository.upenn.edu/cgi/viewcontent. cgi ?article $=1133 \&$ context $=$ gse pubs

Ingersoll, R., \& Kralik, J. M. (2004). The impact of mentoring on teacher retention: What the research says (ECS Research Review). Retrieved from http://www. gse.upenn.edu/pdf/rmi/ECS-RMI-2004.pdf

Ingersoll, R. M., \& Strong, M. (2011). The impact of induction and mentoring programs for beginning teachers: A critical review of the research. Review of Educational Research, 81, 201-233.

Interstate New Teacher Assessment and Support Consortium, Special Education Subcommittee. (2001). Model standards for licensing general and special education teachers of students with disabilities: A resource for state dialogue. Washington, DC: Council of Chief State School Officers.

Jacob, A., Vidyarthi, E., \& Carroll, K. (2012). The irreplaceables: Understanding the real retention crisis in America's urban schools. TNTP. Retrieved from http:// files.eric.ed.gov/fulltext/ED533959.pdf

Johnson, S. M., Berg, J. H., \& Donaldson, M. L. (2005). Who stays in teaching and why: A review of the literature on teacher retention. Cambridge, MA: Harvard Graduate School of Education.

Johnson, S. M., \& Birkeland, S. E. (2003). Sense of success: New teachers explain their career decisions. American Educational Research Journal, 40, 581-617.

Johnson, S. M., \& The Project on the Next Generation of Teachers. (2004). Finders and keepers: Helping teachers survive and thrive in our schools. San Francisco, CA: Jossey-Bass.

Jurow, A. S. (2005). Shifting engagements in figured worlds: Middle school mathematics students' participation in an architectural design project. The Journal of the Learning Sciences, 14, 35-67.

Kraft, M. A., \& Papay, J. P. (2014). Can Professional environments in schools promote teacher development? Explaining heterogeneity in returns to teaching experience. Educational Evaluation and Policy Analysis, 36, 476-50o.

Krieg, J. W. (2006). Teacher quality and attrition. Economics of Education Review, $25,13-27$.

Ladd, H. F. (2011). Teachers' perceptions of their working conditions: How predictive of planned and actual teacher movement? Educational Evaluation and Policy Analysis, 33, 235-261.

Lave, J. (1991). Situated learning in communities of practice. In L. Resnick, J. Levine, \& S. Teasley (Eds.), Perspectives on socially shared cognition (pp. 6382). Washington, DC: American Psychological Association.

Lave, J. (1993). The practice of learning. In S. Chaiklin \& J. Lave (Eds.), Understanding practice: Perspectives on activity and context (pp. 3-32). Cambridge, UK: Cambridge University Press.

Lave, J., \& Wenger, E. (1991). Situated learning-Legitimate peripheral participation. Cambridge, UK: Cambridge University Press.

Leander, K. M. (2002). Locating Latanya: The situated production of identity artifacts in classroom interaction. Research in the Teaching of English, 37, 198-250. 
Liu, E., \& Johnson, S. M. (2006). New teachers' experiences of hiring: Late, rushed, and information-poor. Educational Administration Quarterly, 42, 324-36o.

Lortie, D. C. (1975). Schoolteacher: A sociological study. Chicago, IL: University of Chicago Press.

Luttrell, W., \& Parker, C. (2001). High school students' literacy practices and identities, and the figured world of school. Journal of Research in Reading, 24, 235-247.

Ma, J. Y., \& Singer-Gabella, M. (2011). Learning to teach in the figured world of reform mathematics: Negotiating new models of identity. Journal of Teacher Education, 62, 8-22.

Maier, A., \& Youngs, P. (2009). Teacher preparation programs-And teacher labor markets: How social capital may help explain teachers' career choices. Journal of Teacher Education, 6o, 393-407.

McKinsey \& Company. (2009). The economic impact of the achievement gap on America's schools. Retrieved from http://www.mckinsey.com/insights/ social sector/the economic cost of the us education gap

Measures of Effective Teaching Policy and Practice Brief. (2013). Ensuring fair and reliable measures of effective teaching: Culminating findings from the MET project's three-Year study. The Bill and Melinda Gates Foundation. Retrieved from http://www.metproject.org/downloads/MET Ensuring Fair and Reliable Measures Practitioner Brief.pdf

Michael, A., Andrade, N., \& Bartlett, L. (2007). Figuring "success" in a bilingual high school. The Urban Review, 39, 167-189.

Michie, G. (2012). We don't need another hero: Struggle, hope, and possibility in the age of high-stakes schooling. New York, NY: Teachers College Press.

National Council on Teacher Quality. (2013). Teacher preparation program student performance data models: Six core design principles. Washington, DC: Author. Retrieved from http://www.nctq.org/dmsView/ Teacher_Preparation_Program_Student_Performance_Data_Models_NCTQ

No Child Left Behind Act of 2001, P.L. 107-110, 20 U.S.C. § 6319 (2002).

Oakes, J., Lipton, M., Rogers, J., \& Renee, M. (2006, July). Research as a tool for democratizing education policymaking. Paper presented at International Invitational Symposium on Figuring and Re-Configuring Research, Policy and Practice for the Knowledge Society, Dublin City University, St. Patrick's College, Dublin, Ireland.

Olsen, B. (2008). How "reasons for entry into the profession" illuminate teacher identity development. Teacher Education Quarterly, 35(3), 23-40.

Organisation for Economic Co-Operation and Development. (2005). OECD factbook: Economic, environmental and social statistics. Paris, France: Author.

Penuel, W., Riel, M., Krause, A., \& Frank, K. (2009). Analyzing teachers' professional interactions in a school as social capital: A social network approach. The Teachers College Record, 111, 124-163.

Pratt, D. D. (1992). Conceptions of teaching. Adult Education Quarterly, 42, 203-220. 
Putnam, R. (2001). Bowling alone: The collapse and revival of American community. New York, NY: Simon \& Schuster.

Putnam, R. (2015). Our kids: The American dream in crisis. New York, NY: Simon \& Schuster.

Qian, H., Youngs, P., \& Frank, K. A. (2013). Collective responsibility for learning: Effects of interaction between novice teachers and colleagues. Journal of Educational Change, 14, 445-464.

Rainio, A. P. (2008). Developing the classroom as a "figured world." Journal of Educational Change, 9, 357-364.

Richards, J. (2007, January/February). How effective principals encourage their teachers. Principal Magazine, 86(3), 48-50.

Robertson-Kraft, C., \& Duckworth, A. L. (2014). True grit: Trait-level perseverance and passion for long-term goals predicts effectiveness and retention among novice teachers. Teachers College Record, 116. Retrieved from http://www. tcrecord.org/library/content.asp? contentid $=17352$

Robinson, C. (2007). Figured world of history learning in a social studies methods classroom. The Urban Review, 39, 191-216.

Robinson, V. M. (2007). School leadership and student outcomes: Identifying what works and why (Vol. 41). Winmalee: Australian Council for Educational Leaders.

Rubin, B. C. (2007). Learner identity amid figured worlds: Constructing (in) competence at an urban high school. The Urban Review, 39, 217-249.

Rush, L. S., \& Fecho, B. (2008). When figured worlds collide: Improvisation in an inquiry classroom. Teaching Education, 19, 123-136.

Sloan, K. (2006). Teacher identity and agency in school worlds: Beyond the all-good/all-bad discourse on accountability-explicit curriculum policies. Curriculum Inquiry, 36, 119-152.

Smith, T. M., \& Ingersoll, R. M. (2004). What are the effects of induction and mentoring on beginning teacher turnover? American Educational Research Journal, 41, 681-714.

Spillane, J. P., Halverson, R., \& Diamond, J. B. (2001). Investigating school leadership practice: A distributed perspective. Educational Researcher, 30, 23-28.

Stake, R. E. (2013). Multiple case study analysis. New York, NY: Guilford Press.

Strong, M. (2005). Teacher induction, mentoring and retention: A summary of the research. The New Educator, 1, 181-198.

Tamir, E. (2013). What keeps teachers in and what drives them out: How urban public, urban catholic, and Jewish day schools affect beginning teachers' careers. Teachers College Record, 115(6). Retrieved from http://www.tcrecord. org/library/content.asp? contentid $=16973$

Tamir, E. (2014). Teacher retention and career commitment: Staying, moving, or leaving. In S. Feiman-Nemser, E. Tamir, \& K. Hammerness (Eds.), Inspiring teaching: Preparing teachers to succeed in mission-driven schools (pp. 177-194). Cambridge, MA: Harvard Education Press. 
Teddlie, C., \& Yu, F. (2007). Mixed methods sampling a typology with examples. Journal of Mixed Methods Research, 1, 77-100.

Thorius, K. A. K., \& Scribner, S. M. P. (2014). Teacher learning in urban schools. In E. B. Kozleski \& K. K. Thorius (Eds.), Ability, equity, and culture: Sustaining inclusive urban education reform (pp. 134-150). New York, NY: Teachers College Press.

Urrieta, L. (2007). Figured worlds and education: An introduction to the special issue. The Urban Review, 39, 107-116.

Urrieta, L., Jr., Martin, K., \& Robinson, C. (2011). "I am in school!” African American male youth in a prison/college hybrid figured world. The Urban Review, 43, 491-506.

Vygotsky, L. S. (1978). Mind in society: The development of higher psychological processes (M. Cole, V. John-Steiner, S. Scribner, \& E. Souberman, Eds.). Cambridge, MA: Harvard University Press.

Vygotsky, L. S. (2012). Thought and language. Cambridge, MA: MIT Press.

Wenger, E. (1998). Communities of practice: Learning, meaning and identity. New York, NY: Cambridge University Press.

Wood, A. L. (2005). The importance of principals: Site administrators' roles in novice teacher Induction. American Secondary Education, 33, 39-62.

Youngs, P., Pogodzinski, B., Grogan, E., \& Perrone, F. (2015). Person-organization fit and research on instruction. Educational Researcher, 44, 37-45.

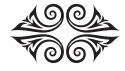

\section{The authors}

Joan Barnatt is an Associate Professor of Education at Elon University, School of Education. Her research examines issues of equity in education, teacher education, and global/international education.

Dianna Gahlsdorf Terrell is an Assistant Professor at Saint Anselm College. Her research interests include education policy; the impact of high stakes tests on curriculum and instruction; civic and democratic education; and the social and political contexts of education.

Lisa Andries D'Souza is an Associate Professor at Assumption College, and chair of the Education Department. Her research interests include teacher education, mentoring and induction, and history/social studies education.

Cindy Jong is an Assistant Professor of Mathematics Education at University of Kentucky in the STEM Education Department. Her research examines issues of equity and identity development within mathematics teacher education. 
Marilyn Cochran-Smith is Cawthorne Professor of Teacher Education for Urban Schools and director of the Ph.D. program in Curriculum and Instruction at the Lynch School of Education at Boston College.

Kara Mitchell Viesca is an Assistant Professor of Culturally and Linguistically Diverse Education at the University of Colorado, Denver. Her research agenda centers on advancing equity in the policy and practice of educator development, particularly for teachers of multilingual learners.

Ann Marie Gleeson, PhD, is a Program Director at Primary Source in Watertown, MA. Her research interests include social studies and global education, as well as professional development.

Patrick McQuillan, an Associate Professor in the Lynch School of Education at Boston College, has a $\mathrm{PhD}$ in cultural anthropology from Brown University. He works extensively in urban secondary schools and his current research interests focus on school reform, with an emphasis on the role of the school principal in transforming urban schools.

Karen Shakman, PhD, is a Research Scientist at Education Development Center, Inc., in Waltham, MA. She leads the Northeast Educator Effectiveness Research Alliance of the Regional Education Laboratory of the Northeast and Islands, leading a range of research evaluation projects focused on teacher and leader effectiveness. 